\title{
THE NECESSITY OF APPLICATION OF FREQUENCY ELECTRIC DRIVES FOR IRRIGATION SYSTEMS
}

\author{
A.B. Kaidar ${ }^{1}$, B.K. Shapkenov ${ }^{1}$, V.P. Markovsky ${ }^{1}$, A.P. Kislov ${ }^{1}$, and A.O. Borzykh ${ }^{1}$ \\ ${ }^{1}$ National Joint Stock Company Toraigyrov University, Pavlodar, Republic of Kazakhstan
}

\begin{abstract}
The article substantiates the possibility of using frequency drives in agricultural production, shows promising areas of their application, shows the positive qualities of frequency drives, which make it possible to confidently compete with gear drives that are widespread in agriculture. It is indicated that the use of a frequency electric drive can reduce the current and mechanical loads due to soft start. Due to the additional control inputs of the frequency converter, it is possible to synchronize the processes on the load or set the change factors for some values depending on others. For example, to establish the dependence of the speed of the irrigation pumping system on the pressure in the system. The process will be optimized because as the load on the pump increases, the flow will increase. Recommendations are given on the choice of the power of the frequency converter, taking into account the rated currents and voltage of the converter and the motor. Recommendations are given on the choice of the power of the frequency converter, taking into account the rated currents and voltage of the converter and the motor. The advantages of starting and braking electric drives with frequency regulation are shown. .
\end{abstract}

\section{Introduction}

The classical method of controlling the flow of pumping units involves throttling of pressure lines and regulation of the number of operating units according to some technical parameter (for example, pressure in the pipeline). In this case, pumping units are selected based on certain design characteristics (as a rule, with a capacity margin) and constantly operate at a constant speed, without taking into account the changing costs caused by variable water consumption. At minimum flow, the pumps continue to run at a constant speed. This, for example, happens at night, when water consumption drops sharply. The main economic effect of the use of variable frequency drives is achieved not due to energy savings, but due to a significant reduction in the cost of repairing water supply networks. The classical method of controlling the flow of pumping units involves throttling the pressure lines and regulating the number of operating units according to some technical parameter (for example, the pressure in the pipeline). In this case, pumping units are selected based on certain design characteristics (as a rule, with a capacity margin) and constantly operate at a constant speed, without taking into account the changing costs caused by variable water consumption. At minimum flow, the pumps continue to run at a constant speed. This, for example, occurs at night, when water consumption drops sharply [1]. The main economic effect of the use of variable frequency drives is achieved not by saving electricity, but by significantly reducing the cost of repairing water supply networks.
In many branches of agriculture, devices are used, the working body of which rotates at a frequency different from that of the drive motor. The conversion of the rotation frequency in most cases is carried out using various types of mechanical converters (gearboxes), and to facilitate starting the engine or prevent jamming, various types of couplings (friction, electromagnetic, etc.) are used [2]. The weight of the gearbox sometimes makes up $80 \%$ of the total weight of the electric drive, the overall dimensions of the gearbox uniquely determine the dimensions of the entire mechanism. In addition, the gearbox creates backlash, changes the elastic nature of the joints, the moment of inertia and other parameters. Large metal consumption, energy losses, vibrations, noise, the complexity of regulation and integration into the working body and the technological process force us to look for ways to obtain different speeds of rotation without mechanical converters [3]. Thus, a promising direction in the development of the electric drive of agricultural machines and mechanisms is to create it without mechanical transmissions.

\section{Main part}

In his Address to the people of Kazakhstan in September 2019, the President of the Republic of Kazakhstan noted the need to increase the area of irrigated land by another 1 million hectares [1]. In this regard, it is necessary to create additional sources of irrigation through the construction of new reservoirs. In total, by 2030 , it is planned to build 28 reservoirs in Akmola, Aktobe, 


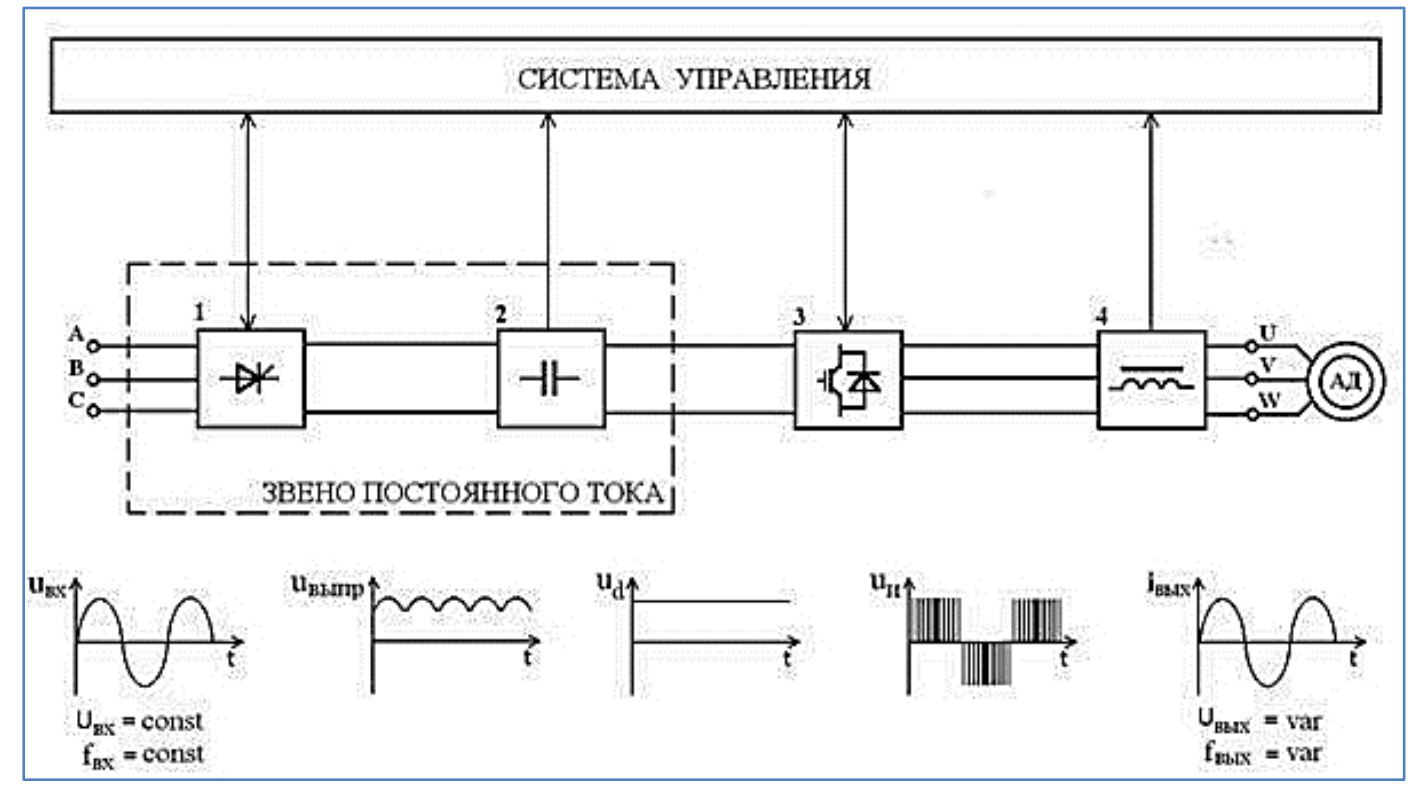

Fig. 1. Modern frequency converter based on double conversion circuits.

Karaganda, Zhambyl, Turkestan, Kyzylorda, East Kazakhstan and West Kazakhstan regions with a total volume of water accumulation of $3.8 \mathrm{~km} 3.470$ thousand hectares of irrigated land will be suspended from these reservoirs. At the same time, 12 reservoirs are planned to be used both for irrigation and to eliminate the threat of floods in 70 settlements. The construction of reservoirs will provide employment for 29 thousand jobs in rural areas [4].

Given that in an arid climate, high crop yields guarantee the use of irrigation systems, the area of irrigated land is increasing annually.

The heart of the modern irrigation system is the pumping station. Its performance depends on the area and volume of irrigation, as well as on the height of the water rise. The introduction of automatic control and regulation means can significantly increase efficiency and economic feasibility.

Most modern frequency converters are based on double conversion circuits [5]. This technical solution has the following advantages: [6].

- Ability to change the frequency both up and down

- The output voltage is purely sinusoidal [7].

- Low content of higher harmonics (absence) [8].

- Smooth and high-precision regulation of the frequency of the motor supply voltage.

Such a Frequency Converter (FC) consists of three blocks (Fig. 1) [7]:

1. Diode or thyristor rectifier with capacitive, inductive or combined filters. This node performs line voltage rectification and smoothing.

2. Inverting unit. This element performs the reverse conversion of DC voltage into AC voltage. The inductive element at the output filters the DC component, as well as high-frequency noise, the presence of which negatively affects the operation of the electric motor.
3. Control circuit based on microprocessor. Its main functions are to set the frequency of the output voltage and current.

The frequency of the current at the output of the inverter is determined by the width or duration of the control pulses [9] from the control circuit (pulse width or frequency modulation). The processor also provides communication with remote control points, automatic feedback control according to the mechanical and electrical characteristics of the electrical machine connected to it, and other functions.

Thus, with frequency regulation, the supply voltage is first converted into a constant voltage, then inverted into an alternating voltage of the required frequency [10].

When designing a variable frequency drive, many nuances must be taken into account. When choosing an inverter, they are guided by the following criteria:

- Purpose of the $v$ transducer. Many manufacturers produce frequency inverters designed for electric motors of pumps, elevators, electric drives of ventilation systems, as well as universal devices for general industrial purposes. Specialized VFDs are produced for specific technological equipment. Their adaptability is significantly limited. General industrial frequency controllers can be configured for different drives [11].

- A way to manage and support various communication protocols. Variable frequency drives are usually integrated into complex automation and remote monitoring and control systems. The frequency converter must be equipped with a controller that supports communication according to the protocol used in a specific process control system.

- Rated electrical power of the converter. It should be $15-30 \%$ more than the same parameter of the electric motor [12]. When calculating the power, the starting currents of the electric machine, the peak loads on the engine and their duration are taken into account. Errors 


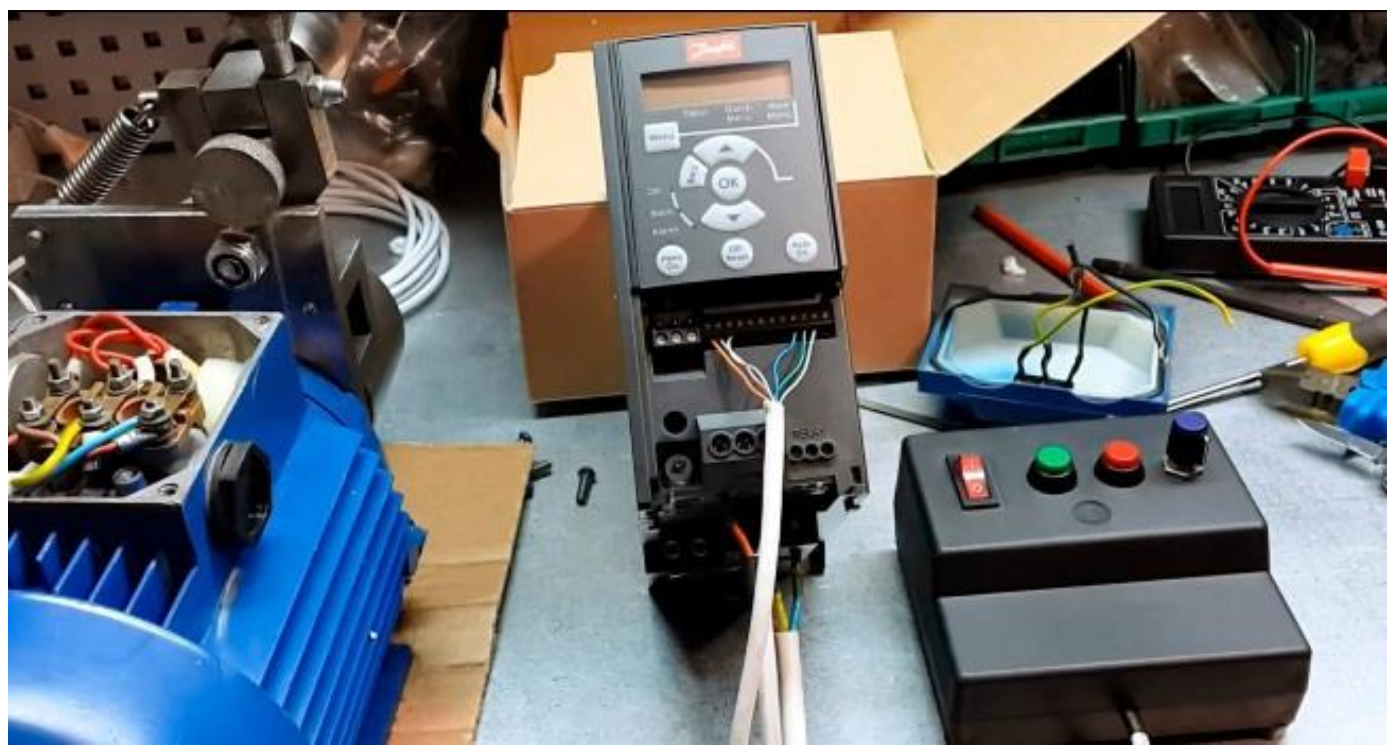

Fig. 2. Testing the converter in laboratory conditions.

lead to overheating of the inverter, failure of power transistors or thyristors.

- Range and control accuracy. The frequency change interval and the accuracy of its assignment must correspond to the requirements of the technological process conditions. The ability to change the frequency with scalar converters $1: 10$, if a wider range is required, a vector control inverter is required [13].

- Electromagnetic compatibility. The frequency converter is sensitive to electromagnetic interference and is itself a source of it. The choice of a device is based on the conditions for its installation. If necessary, it may be necessary to install it in a separate room, connect special filters and use shielded cables. Danfoss manufactures converters with built-in EM filters [14].

- The presence of the functions of shutdown of the motor in case of overheating, phase imbalance, overloads, other emergency and abnormal operating modes.

- Availability of automated event management. To synchronize the operation of industrial equipment, VFDs are needed that have regulation functions upon reaching a certain value of technological parameters [15].

The number of inputs and outputs for connecting remote control and monitoring devices. In the case of modernization of the automatic control system of the automatic control system or the complication of the automatic system with a thyristor drive (ASTP), it is recommended to choose a frequency converter with an excessive number of analog and discrete connectors. For electric drives of automated systems, it is recommended to select a frequency regulator with built-in memory and an event log function [16].

Rated current and voltage. The electrical parameters of the inverter must correspond to the characteristics of the electric motor.

The choice of a frequency regulator for industrial equipment is made on the basis of calculations using specialized methods. The slightest mistakes can lead to accidents, which can have unpredictable consequences (Fig. 2). It is advisable to entrust the design of the electric drive and the selection of the inverter to the automation specialists. The correct choice of inverter provides energy savings of up to $40-50 \%$, reduces the cost of repair and maintenance of the electric drive and gives a good economic effect [17].

Now in the Pavlodar region, of the 76.3 thousand hectares of irrigated land left from Soviet times, only 1520 thousand are watered. On the largest irrigation system in the region, Chernoyarsk, about 3,700 hectares are cultivated.

The irrigation system was built as a single and indivisible one, designed for one owner - the state farm "Chernoyarsky". It includes three pumping stations, 57 kilometers of main pipeline and 230 kilometers of distribution water pipelines. The drive is unregulated.

The need to use frequency drives, as for other agricultural consumers, is due to the fact that each peasant farm purchases for its own needs based on its capabilities, the amount of subsidies, market offers at the time of purchase of equipment. Thus, it turns out that this year they buy irrigation machines for a pressure of 7 atmospheres, next year from another manufacturer for 5 atmospheres, etc. [17]. Therefore, the purchase of a frequency drive by farms is beneficial, since it allows you to adjust the rotational speed of the drive mechanisms in a wide range [18].

A number of companies Siemens, ABB, WEG, etc. Produce various specialized drives. Among the Russian, for example, the engineering company "Synergy" [2] specializes in the creation of automated control systems for technological processes. Many developments are based on equipment from the Danfoss Drivers product basket. One of the typical projects using VACON frequency converters was implemented at an irrigation pumping station of a farm in the Astrakhan region. As a result of automation, pumps have become more efficient, improved reliability of all equipment, reduced energy 


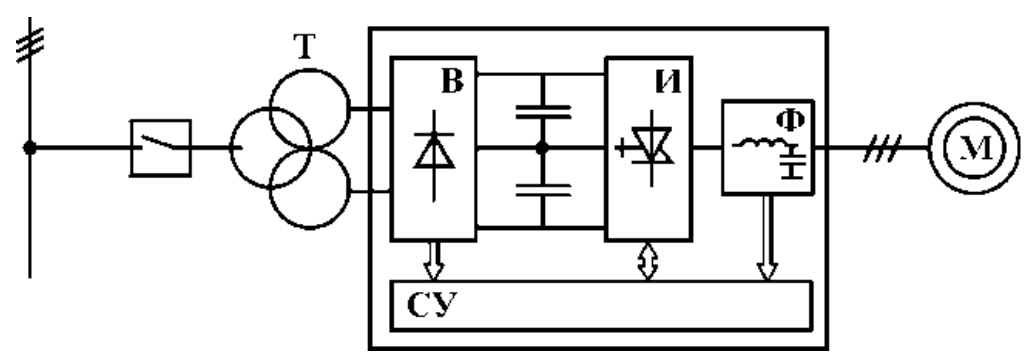

a)

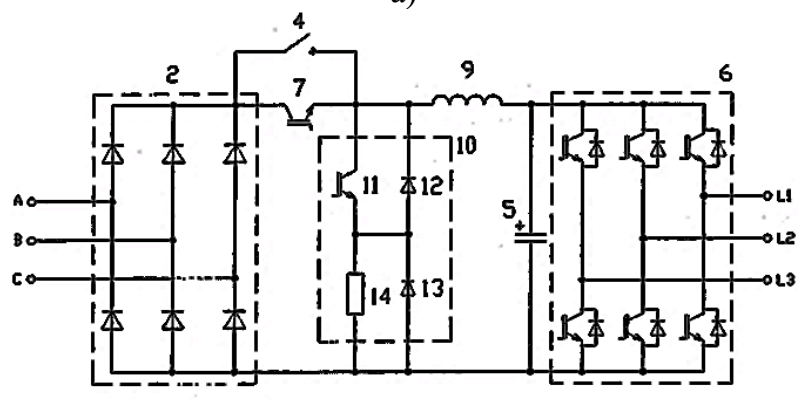

b)

Fig. 3. Scheme of a standard frequency converter on thyristors (a) on power transistors (b).

consumption and lower operating costs. A pilot irrigation system was also created in the neighboring Novosibirsk region [3]. Water for irrigation of farmland comes from the open canal first into the front chamber - a structure in the form of an extension of the main water conduit. Then with the help of pumps through pipelines to the sprinklers. There are 5 units in the pumping group.

The solution was realized by installing a VACON 100 FLOW frequency converter with a power of $75 \mathrm{~kW}$ for each pumping unit. This circuit is the most energy efficient and reliable. This made it possible to get away from complex switching schemes, and also ensured convenient installation and ease of use. The device has an intuitive graphical control panel with setup wizards.

To control the pumping unit, a frequency converter is used - an inverter with PWM control. For example, such a converter is convenient to use for pumping stations of irrigation installations in the Chernoyarsk rural district (Pavlodar), where the area of irrigated land is 2735 hectares. Such control provides a lot of advantages, but also creates some problems when choosing certain technical solutions.

The development and production of a wide range of high-power high-voltage transistor IGBT modules has made it possible to realize multiphase power switches directly controlled by digital signals. Programmable computing means made it possible to form numerical sequences at the inputs of switches that provide signals for frequency control of asynchronous motors. Development and serial production of single-chip microcontrollers with large computing resources made it possible to switch to servo drives with digital controllers.

Power frequency converters, as a rule, are implemented according to a circuit containing a rectifier based on powerful power diodes or transistors and an inverter (controlled switch) on IGBT transistors shunted by diodes (Figure 3 ).
The input stage rectifies the supplied sinusoidal mains voltage, which, after being smoothed by an inductive-capacitive filter, serves as a power source for the controlled inverter, which, under the action of digital control commands, generates a pulse modulation signal that generates sinusoidal currents. in the stator windings with parameters that ensure the required operating mode of the electric motor.

The digital control of the power converter is carried out using microprocessor equipment and software corresponding to the tasks set. The computing device generates control signals for 52 modules in real time, as well as processes signals from measuring systems that control the operation of the drive.

Power devices and control computers are integrated into a structurally designed industrial product called a frequency converter.

In industrial equipment, there are two main types of frequency converters:

- branded converters for specific types of equipment.

- universal frequency converters are designed for universal control of the AM operation in user modes.

Adjustment and control of the operating modes of the frequency converter can be carried out using the control panel equipped with a screen to display the entered information. For simple scalar frequency control, you can use a set of simple logic functions available in the factory settings of the controller and the built-in PID controller.

To implement more complex control modes using signals from feedback sensors, it is necessary to develop the structure and algorithm of the ACS, which should be programmed using a connected external computer.

Most manufacturers produce a range of frequency converters that differ in input and output electrical characteristics, power, design and other parameters. Additional external elements can be used to connect to 


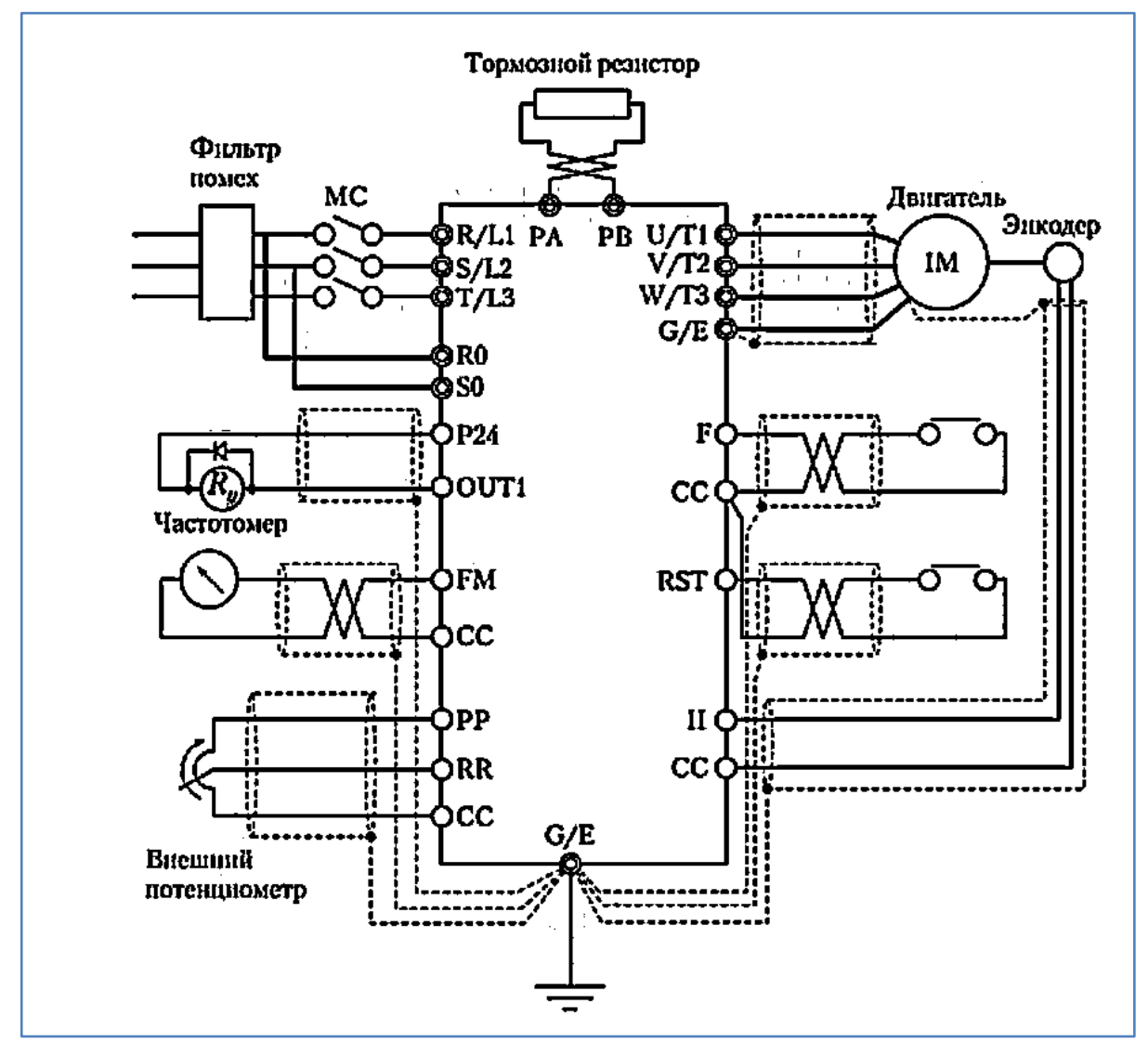

Fig. 4. Example of connection of power circuits and control circuits of the frequency converter.

external equipment (mains, motor): magnetic starters, transformers, chokes.

It is necessary to distinguish between different types of signals and use a separate cable for each. Different types of signals can influence each other. In practice, this separation is common, for example the cable from the pressure transducer can be connected directly to the frequency converter.

Figure 4 shows the recommended connection for a frequency converter with different circuits and control signals.

The following types of signals can be distinguished:

- analog - voltage or current signals $(0 \ldots 10 \mathrm{~V}, 0 / 4 \ldots$ $20 \mathrm{~mA}$ ), the value of which changes slowly or infrequently, usually these are control or measurement signals;

- discrete voltage or current signals $(0 \ldots 10 \mathrm{~V}, 0 / 4 \ldots$ $20 \mathrm{~mA}$ ), which can take only two rarely changing values (high or low);

- digital (data) - voltage signals $(0 \ldots 5 \mathrm{~V}, 0 \ldots 10 \mathrm{~V})$, which change quickly and with high frequency, usually signals from RS232, RS485, etc. ports;

- relay - relay contacts $(0 \ldots 220 \mathrm{~V} \mathrm{AC})$ can include inductive currents depending on the connected load (external relays, lamps, valves, brakes, etc.).

When choosing the power of the frequency converter, it is necessary to rely not only on the power of the electric motor, but also on the rated currents and voltages of the converter and the motor. The point is that the specified power rating of the frequency converter only applies to its operation with a standard 4-pole induction motor in standard applications.

Real drives have many aspects that can lead to an increase in the current load of the drive, for example during startup. In general, the use of a frequency drive allows you to reduce the current and mechanical loads due to soft start. For example, the starting current is reduced from $600 \%$ to $100-150 \%$ of the rated current. So, with the direct start-up of the pumping station in the Aktogay region (Fig. 5) of the Pavlodar region when powered from a $0.4 \mathrm{kV}$ power transmission line, the phase voltage value decreased to $180 \mathrm{~V}$, and the current strength reached 5-7 times. nominal cost.

The adjustable frequency drive can easily provide 10 : 1 speed control, but when the motor is running at low speeds, its own fan may not be powerful enough. Monitor the motor temperature and provide forced ventilation.

Since the frequency converter is a powerful source of high-frequency harmonics, a shielded cable with a minimum length must be used for connecting the motors. Such a cable must be laid at a distance of at least 100 $\mathrm{mm}$ from other cables. This will minimize crosstalk. If cables need to be crossed, the crossing is done at a 90 degree angle.

Smooth start-up of the frequency converter reduces the required generator power. Since with such a start, the current decreases 4-6 times, then the generator power can be reduced by the same number of times. However, a contactor must be installed between the generator and 


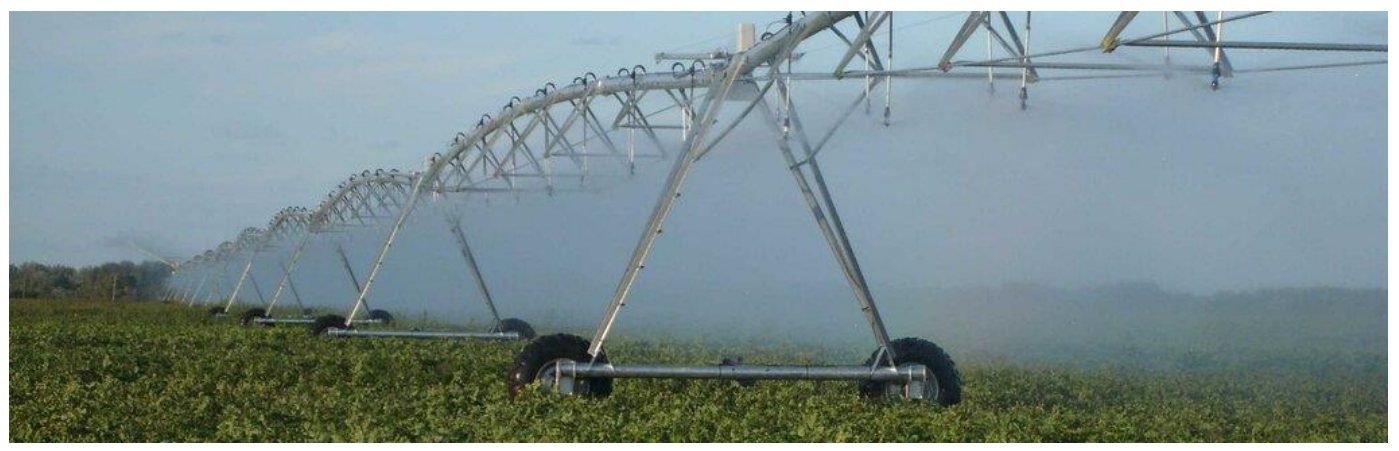

Fig. 5. Irrigation 2018 2IP "Pivot" LLP "Aktogay-Agro".

the drive, controlled by the relay output of the frequency drive. This protects the frequency converter from dangerous overvoltages.

Three-phase frequency converters can be supplied from a single-phase network, but their output current must not exceed $50 \%$ of the nominal.

The savings come from several reasons. Firstly, due to the growth of $\cos \varphi$ up to 0.98 , i.e. the maximum power is used to perform useful work, the minimum is lost. Secondly, a coefficient close to this is obtained at all engine operating modes.

1 Without a frequency converter, induction motors have $\cos \varphi=0.3-0.4$ at low loads. Thirdly, there is no need for additional mechanical adjustments (dampers, throttles, valves, brakes, etc.), Everything is done electronically. With such a control device, savings can be up to $50 \%$.

Due to the additional control inputs of the frequency converter, it is possible to synchronize processes on the load or set the ratios of changes in some values depending on others. For example, set the dependence of the speed of the pumping system of irrigation on the pressure in the system. The process will be optimized because as the load on the pump increases, the flow will increase.

For additional protection, in addition to short shielded cables, line chokes and bypass capacitors are used. The inductor also limits the inrush current when turned on.

Reliable heat dissipation is essential for the smooth operation of the frequency drive. When using high protection classes, for example IP 54 and higher, this heat dissipation is difficult or expensive to achieve. Therefore, it is possible to use a separate cabinet with a high protection class, in which modules with a lower class can be installed and general ventilation and cooling is carried out.

To reduce costs, one frequency converter can be used to control several motors. Its power must be selected with a margin of $10-15 \%$ of the total power of all electric motors. It is necessary to minimize the length of the motor cables and it is highly desirable to install a motor choke.

Most frequency converters do not allow you to disconnect or connect motors with contactors while the frequency converter is running [4]. This is done only with the drive stop command.
To obtain the maximum characteristics of the electric drive, such as: power factor, efficiency, overload capacity, smoothness of regulation, durability, it is necessary to correctly choose the ratio between the change in operating frequency and the voltage at the output of the frequency converter.

The voltage variation function depends on the nature of the load torque. With constant torque, the motor stator voltage must be controlled in proportion to the frequency (scalar control $\mathrm{U} / \mathrm{f}=$ const). For example, a fan has a different $\mathrm{U} / \mathrm{f} \cdot \mathrm{f}=$ const ratio. If you increase the frequency by 2 times, then the voltage must be increased by 4 (vector control). There are drives with more complex control functions.

\section{Results}

The use of a frequency electric drive [5] allows to reduce the current and mechanical loads due to the soft start. For example, the starting current is reduced from $600 \%$ to $100-150 \%$ of the rated current. So, with the direct start-up of the pumping station in the Aktogay district of the Pavlodar region when powered by a $0.4 \mathrm{kV}$ power transmission line, the phase voltage value decreased to $180 \mathrm{~V}$, and the current reached 5-7 times of the nominal value. ...

The adjustable frequency drive can easily provide 10 : 1 speed control, but when the motor is running at low speeds, its own fan may not be powerful enough.

The soft start provided by the frequency converter reduces the required generator power. Since with such a start, the current decreases 4-6 times, then the generator power can be reduced by the same number of times. However, a contactor must be installed between the generator and the drive, controlled by the relay output of the frequency drive. This protects the frequency converter from dangerous overvoltages.

The savings come from several reasons. Firstly, due to the growth of $\cos \varphi$ up to 0.98 , i.e. the maximum power is used to perform useful work, the minimum is lost. Secondly, a coefficient close to this is obtained at all engine operating modes.

Without a frequency converter, light-load asynchronous motors have $\cos \varphi=0.3-0.4$. Thirdly, there is no need for additional mechanical adjustments (dampers, throttles, valves, brakes, etc.), Everything is 
done electronically. With such a control device, savings can be up to $50 \%$.

Due to the additional control inputs of the frequency converter, it is possible to synchronize processes on the load or set the ratios of changes in some values depending on others. For example, set the dependence of the speed of the pumping system of irrigation on the pressure in the system. The process will be optimized because as the load on the pump increases, the flow will increase.

\section{Conclusion}

The use of a frequency electric drive for a number of agricultural facilities that require regulation of the speed of an electric drive can improve efficiency and provide significant energy savings from 10 to $30 \%$.

The savings come from several reasons. First, due to the growth of the cosine phi to 0.98 , i.e. the maximum power is used to perform useful work, the minimum is lost. Secondly, a coefficient close to this is obtained at all engine operating modes.

In addition, the frequency electric drive allows you to get new control qualities. This is reflected in the rejection of additional mechanical devices that create losses and reduce the reliability of systems: brakes, dampers, throttles, gate valves, control valves, etc.

When using a frequency drive where braking is required, for example in feed preparation systems, braking, for example, can be carried out due to the reverse rotation of the electromagnetic field in the stator of the electric motor. By changing only the functional relationship between frequency and voltage, we get a different drive, without changing anything in the mechanics.

\section{References}

1. V hode modernızatsı 1rrıgatsıonno infrastrýktýry Kazahstana býdet sozdano 88 tys.rabochıh mest (7 aprelia 2020) [Electronic resource] Available at: https:// primeminister.kz/ru/news/v-hode-modernizaciiirrigacionnoy-infrastruktury-kazahstana-budetsozdano-88-tys-rabochih-mest-73818

2. J.V. Torkunova, M.N. Habrieva, A.R. Birialtceva, B.K. Shapkenov, Qualimetric approach to solving the problems of innovative development of Russian power industry, NASA ADS Abstract Service/ E3S Web of Conferences, 124, International Scientific and Technical Conference Smart Energy Systems 2019 (SES-2019), Kazan, Russia (18-20 September 2019) DOI: $10.1051 / \mathrm{e} 3$ sconf/201912404012

3. Avtomatizats11a nasosno1stants11 oroshen11a na osnove preobrazovatele1 chastoty VACON [Electronic resource] Available at: https://drives.ru/proekty/vodosnabzhenie-ivodootvedenie /avtomatizacia- nasosnoy-stanciiastrakyan/https://drives.ru/proekty/vodosnabzhenie-ivodootvedenie/avtomatizacia-nasosnoy-stanciiastrakyan/
4. A.B. Ka1dar, M.B. Ka1dar, B.K. Shapkenov, V.P. Markovsk11, Avtomatıka sistem vodosnabjenı1a Smart Home, Vestnık PGÝ, Serıa energetıcheska1a, 1, 177186 (2019) ISSN: 1811-1858

5. A.B. Ka1dar, M.B. Ka1dar, B.K. Shapkenov, V.P. Markovsk11, A.P. Kislov, S.B. Ramazanov, Analız vysokochastotnyh preobrazovatele1 na IGBT 1 MOSFET tranzıstorah, Materıaly mejdýnarodno1 naýchno1 konferents11 molodyh ýchenyh, magistrantov, stýdentov 1 shkolnıkov «HH SATPAEVSKIE ChTENIIa», Pavlodar, 18 (2020) ISBN: 978-601-345056-8

6. V.S. Kopyrın, B.K. Shapkenov, Diagnostıka avarınyh rejımov sistem s preobrazovatelnymı ýstanovkamı, Sb. dokladov Vsesoiýzno1 naýchno-tehnıch. konf. Sostoianie 1 perspektıvy razvitı1a elektrotehnologi1, Tret1 Benardosovskie chteni1a, Ivanovo, 2, 127 (1987)

7. B.K. Shapkenov, V.P. Markovsk11, A.P. Kıslov, M.B. Ka1dar, A.B. Ka1dar, A.V. Neftısov, M.E. Volgın, B.Ý. Beisembaev, Topologi1a silovo1 chast1 mnogoýrovnevyh preobrazovatele1 elektrıchesko1 energ11 dlıa avtonomnyh elektroenergetıcheskıh sistem, «HIH Sátbaev oqýlary» jas ǵalymdar, magıstranttar, stýdentter men mektep oqýshylarynyń: halyqar. ǵyl. konf. mat-dary Akademık Q.I. Sátbaevtyń 120 jyldyǵyna arnalǵan, Pavlodar: S. Toratǵyrov atyndaǵy PMÝ (2019) ISBN: 978-601-238-907-4, «Stýdentter», 12, 296 (2019) ISBN: 978-601-238-919-7

8. A.B. Kaidar, M.B. Kaidar, B.K. Shapkenov, V.P. Markovskiy, A.P. Kislov, Control of hybrid AC/DC microgrid under islanding operational conditions, «HIH Sátbaev oqýlary» jas ǵalymdar, magıstranttar, stýdentter men mektep oqýshylarynyń : halyqar. ǵyl. konf. mat-dary Akademık Q.I. Sátbaevtyń 120 jyldyǵyna arnalǵan, Pavlodar: S. Toratǵyrov atyndaǵy PMÝ (2019) ISBN: 978-601-238-907-4, «Jas ǵalymdar», 21, 420 (2019) ISBN: 978-601-238-930-2

9. A.P. Kıslov, B.K. Shapkenov, V.P. Markovsk11, M.B. Kaıdar, A.B. Kaıdar, A.K. Jýmadırova, B.Ý. Beısembaev, Analız trebovanı, prediavliaemyh $\mathrm{k}$ s1stemam avtonomnogo elektropitanı1a s ýchetom obespechenı1a elektromagnitno1 sovmestımost1, «HIH Sátbaev oqýlary» jas ǵalymdar, magıstranttar, stýdentter men mektep oqýshylarynyń: halyqar. ǵyl. konf. mat-dary Akademık Q.I. Sátbaevtyń 120 jyldyǵyna arnalǵan, Pavlodar: S. Toraiǵyrov atyndaǵy PMÝ (2019) ISBN: 978-601-238-907-4, «Jas ǵalymdar», 21, 420 (2019) ISBN: 978-601-238-930-2

10. A.B. Ka1dar, M.B. Ka1dar, B.K. Shapkenov, A.P. Kıslov, V.P. Markovskı1, Snijenıe vysokochastotnyh sostavlıaiýlh aktıvnymı filtramı $\mathrm{v}$ setıah $\mathrm{S}$ preobrazovatelıamı, PMÝ Habarshysy, Energetıkalyq ser11asy, 3, 54-67 (2018) ISSN: 1811-1858

11. A.B. Ka1dar, M.B. Ka1dar, B.K. Shapkenov, V.P. Markovsk11, Avtomatıka s1stem vodosnabjenı1a Smart Home, Vestnık PGÝ, 1, 177-186 (2019) ISSN: 18111858

12. A.B. Ka1dar, M.B. Ka1dar, B.K. Shapkenov, V.P. Markovskı1, A.P. Kıslov, Snijenıe nesımmetr11 1 fliker 
effekta v elektrotehnıcheskıh s1stemah, Vestnık PGÝ, Energetıcheska1a ser11a, 3, 76-85 (2018) ISSN: 18111858

13. A.B. Kaidar, M.B. Kaidar, B.K. Shapkenov, V.P. Markovsky, A.P. Kislov, The comparisons between IGBT chopper-rectifiers and thyristor rectifiers, Naýchnyı jýrnal «Vestnık PGÝ», Pavlodar, 1, 200-210 (2018)

14. B.K. Shapkenov, V.P. Markovskĭ, M.B. Kaĭdar, A.B. Kaĭdar, O.M. Talıpov, R.R. Rýslanov, S.A. Danılenko, E.B. Turlybek, Povyshenıe chývstvitelnost 1 bystrodeřstvı1a za1t nızkovoltnyh raspredelıtelnyh seteř v selskoĭ mestnost1, Vestnık PGÝ, ISSN 1811-1858, Ser11a energetıcheska1a, 1, 474-487 (2020)

15. B.K. Shapkenov, V.P. Markovskiy, A.P. Kislov, A.B. Kaidar, M.B. Kaidar, O.A. Andreeva, Sh.S. Kuanyshbay, Calculation and modeling of emergency modes in distribution networks, Vestnık PGÝ, Serıı energetıcheska1a, 1, 487-497 (2020) ISSN: 1811-1858

16. S.K. Sheryazov, S.S. Issenov, A.B. Kaidar, Specifics of the choice of electric energy conversion and storage systems in wind power plants for agriculture, Toratǵyrov ýnıversıtetiniń 60 jyldyǵyna arnalǵan «HII Toraı́grov oqýlary»: Halyqaralyq ǵylymı-tájirıbelik konferentsıasynyń materialdary, Pavlodar: Toraı́gyrov ýnıversiteti, 5, 542 (2020) ISBN: 978-601-345-104-6 (379-386, 2020) ISBN: 978-601-345-108-4

17. C.K. Sheriazov, S.S. Isenov, A.B. Ka1dar, Predposylk1 vnedrenı1a SMART GRID seteıs vetroenergetıcheskımı ýstanovkamı $\mathrm{V}$ selskom hozıa1stve, Toralǵyrov ýnıversıtetiniń 60 jyldyǵyna arnalǵan «HII Toraı́gyrov oqýlary»: Halyqaralyq ǵylymı-tájirıbelik konferentsıasynyń materialdary, Pavlodar: Toraı́grov ýnıversiteti, 5, 542 (2020) ISBN: 978-601-345-104-6 (386-395, 2020) ISBN: 978-601-345-108-4

18. C.K. Sheriazov, S.S. Isenov, A.B. Ka1dar, Ýnıversalnost 1 effektıvnost chastotnyh elektroprıvodov dlıa sistem polıva, Toraı́gyrov ýnıversitetiniń 60 jyldyǵyna arnalǵan «HII Tora1ǵyrov oqýlary»: Halyqaralyq ǵylymı-tájirıbelik konferentsısasynyn materıaldary, Pavlodar: Toraı́grov ýnıversıteti, 5, 542, 2020) ISBN: 978-601-345-104-6 (395-403, 2020) ISBN: 978-601-345-108-4 